\title{
Б.В. Задорожна
}

\section{КЛІНІЧНО-ДОППЛЕРОГРАФІЧНІ ЗІСТАВЛЕННЯ ПРИ СИНДРОМІ ВЕГЕТО-СУДИННОЇ ДИСТОНІЇ ВІДДАЛЕНОГО ПЕРІОДУ ЧЕРЕПНО-МОЗКОВОЇ ТРАВМИ}

Львівський національний медичний університет ім. Данила Галицького

\begin{abstract}
Резюме. Наведені результати допплерографічного дослідження магістральних артерій голови (МАГ) хворих у зіставленні з клінічною симптоматикою домінуючого синдрому вегето-судинної дистонії віддаленого періоду черепно-мозкової травми (ЧМТ).
\end{abstract}

Вступ. За останні роки уявлення про травматичну хворобу головного мозку (ТХГМ) отримало суттєвий розвиток. Завдяки застосуванню методів нейровізуалізації (КТ, МРТ тощо) з'явилася можливість здійснювати прижиттєві клінічноанатомічні зіставлення у віддаленому періоді ЧМТ $[1,6,8]$. Нові нейрофізіологічні, нейрохімічні, імунологічні дані дозволили уточнити патогенез ряду неврологічних синдромів віддаленого періоду ЧМТ, зокрема, легкої, яка не має чіткого морфологічного субстрату в гострому періоді $[4,6]$.

Синдром вегето-судинної дистонії, за даними ряду авторів, домінує в клінічній картині віддаленого періоду ЧМТ у 51-58,2 \% хворих [5, 7]. Поруч 3 цим, гемодинамічні розлади мозкового кровообігу в даної категорії післятравматичних осіб вивчені недостатньо.

Мета дослідження. Вивчити особливості церебральної гемодинаміки при синдромі вегетосудинної дистонії у віддаленому періоді ЧМТ.

Матеріал і методи. Для розв'язання поставлених завдань проведено комплексне клінічнопараклінічне обстеження 43 пацієнтів у віддаленому періоді ЧМТ, у яких у клінічній картині ТХГМ домінував синдром вегето-судинної дистонії. Факт перенесеної травми, іiі тяжкість та характер встановлювали на основі вивчення анамнезу і медичних даних лікувальних закладів, де хворі перебували на лікуванні в гострому періоді травми. Тяжкість травми визначалася відповідно до прийнятої у нашій країні класифікації черепно-мозкових травм [9]. Середній вік пацієнтів

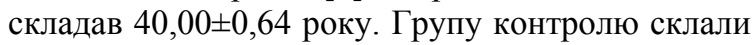
22 практично здорові особи середнього віку $38,27 \pm 1,81$ року. Пацієнти обстежувалися через шість місяців із моменту отримання травми до 20 і більше років, що дозволило охопити практично увесь резидуальний період перебігу ТХГМ.

Обстеження МАГ проводилося транскраніальним лінійним допплерографом Multigon $500 \mathrm{M}$ виробництва американської фірми „Multigon Industries" (Inc. USA) ультразвуковим датчиком пульсуючого режиму з частотою випромінювання 2 МГц. Ефективність методу транскраніальної допплерографії (ТКД) визначається неінвазивністю, інформативністю, можливістю використання в динаміці як на амбулаторному, так і стаціонар(C) Б.В. Задорожна, 2013
Ключові слова: віддалений період ЧМТ, синдром вегето-судинної дистонії, транскраніальна допплерографія судин голови.

ному етапі. Здійснювалася поетапна локація інтракраніальних (передніх (ПМА), середніх (CMA), задніх мозкових (ЗМА, хребтових (ХА) та основної (ОА)) артерій. Прилад визначав систолічну та діастолічну швидкість по локованих судинах, на основі чого автоматично вираховував середню швидкість току крові по судині (СШК). Оскільки в зарубіжних та вітчизняних виданнях найбільш інформативною вважається середня швидкість лінійного кровотоку, то саме іiі ми прийняли за основу при розгляді наявності чи відсутності патологічних змін церебральних судин $[2$, $3,10,11]$.

Статистичну обробку отриманих даних здійснювали за допомогою персонального комп'ютера та програмних статистичних пакетів Windows XP, Microsoft Word, Excel (Office XP), Quattro Pro для Windows (Borland International 1993, версія 5.0). Рівень вірогідності усіх цифрових показників (р) визначався за допомогою параметричного критерію $\mathrm{t}$ (Стьюдента).

Результати дослідження та їх обговорення. Синдром вегето-судинної дистонії був провідним у клінічній картині ТХГМ у хворих, які перенесли легку ЧМТ. Пацієнтів із перенесеним струсом головного мозку було вдвічі більше $(69,8$ \%), ніж осіб із забоєм головного мозку легкого ступеня (30,2 \%). Синдром вегето-судинної дистонії найчастіше виявляли в пацієнтів із давністю травми від одного до п'яти років, незначно переважав в осіб чоловічої статі $(53,5 \%)$ і частіше траплявся в осіб віком 40-49 років і до 30 років $(37,2 \%$ та 30,2\% відповідно).

Синдром вегето-судинної дистонії проявлявся як перманентними (вегето-судинними і вегетовісцеральними) розладами, так і пароксизмальними станами (панічними атаками). Клінічно простежувалися: постуральна тахікардія, ортостатична лабільність, порушення терморегуляції (субфебрилітет, термоасиметріі), екстралемніскові розлади чутливості (плямисто-мозаїчного характеру), парестезії і соматалгії. Пароксизмальні розлади змішаного (симпатоадреналового і вагоінсулярного характеру) проявлялися загальною слабкістю, болем голови, запамороченням, серцебиттям, лабільністю артеріального тиску і іншими симптомами, а також вітальним страхом. На- 
ші спостереження не розходяться 3 існуючим уявленням про даний синдром як про психовегетативний, що має в собі компоненти психопатологічних (зазвичай емоційних) порушень. Вегетативну дистонію в поєднанні з астенічним синдромом виявили в 34 пацієнтів. Вочевидь, розлади вегетативної регуляції внаслідок ураження структур лімбікоретикулярного комплексу значно сприяють розвитку астенічного синдрому.

При проведенні ТКД МАГ здорових осіб ми отримали наступні значення СШК: у правій CMA - 53,10 $\pm 1,69 \mathrm{~cm} / \mathrm{c}$, у лівій CMA $55,98 \pm 1,63 \mathrm{~cm} / \mathrm{c}$, у правій ПМА - 41,70 $\pm 1,15 \mathrm{~cm} / \mathrm{c}$, у лівій ПМА - 44,61 11,62 см/c, у правій ХА -

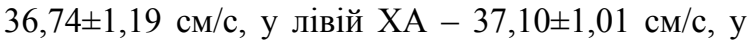
$\mathrm{OA} \mathrm{-} \mathrm{37,44 \pm 1,12} \mathrm{cм/c,} \mathrm{у} \mathrm{правій} \mathrm{3МА} \mathrm{-}$ $35,81 \pm 0,86 \mathrm{~cm} / \mathrm{c}$, у лівій $3 \mathrm{MA}-36,58 \pm 0,80 \mathrm{~cm} / \mathrm{c}$.

При обстеженні МАГ пацієнтів із провідним у клінічній картині віддаленого періоду ЧМТ синдромом вегето-судинної дистонії реєструвався вірогідний $(\mathrm{p}<0,05)$ ріст СШК у правій СМА

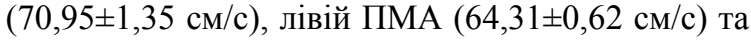
правій ЗМА $(41,71 \pm 1,45 \mathrm{~cm} / \mathrm{c})$ по відношенню до контрольної групи, тоді як показники СШК у лівій СМА, правій ПМА, ОА та лівій ЗМА від контрольних параметрів суттєво не відрізнялися ( $>00,05$ ). Так, СШК становила: $56,80 \pm 0,36$ см/с у

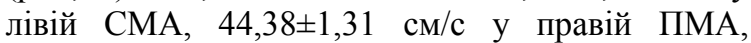
$37,08 \pm 0,97 \mathrm{~cm} / \mathrm{c}$ у ОА та $34,87 \pm 0,61 \mathrm{~cm} / \mathrm{c}$ у лівій 3MA.

Вірогідних відмінностей току крові у двох ХА в обстежених осіб із домінуючим у віддаленому періоді ЧМТ синдромом вегето-судинної дистонії порівняно з контролем ми також не відмітили ( $>0,05)$. У них СШК у лівій ХА складала в середньому $36,17 \pm 0,85 \mathrm{~cm} / \mathrm{c}$, у правій ХА $35,32 \pm 0,55 \mathrm{~cm} / \mathrm{c}$.

\section{Висновок}

Підводячи підсумки проведених нами досліджень, можна дійти висновку, що при домінуючому у віддаленому періоді черепно-мозкової травми синдромі вегето-судинної дистонії поруч із клінічними проявами захворювання наявні розлади церебральної гемодинаміки в різних судинах обох півкуль головного мозку, а саме - ріст кровотоку по правій середній мозковій артерії, лівій передній та правій задній мозкових артеріях, що, ймовірно, може свідчити про різноскеровані механізми порушення авторегуляції магістральних артерій голови в цих хворих та, очевидно, може мати певний зв'язок з особливостями клінічних проявів, що потребує подальших досліджень.

Перспективи подальших досліджень. Ми сподіваємося, що виявлені нами гемодинамічні розлади в різних судинах обох півкуль головного мозку при синдромі вегето-судинної дистонії віддаленого періоду ЧМТ можуть мати певне діагностичне і прогностичне значення та допомо- жуть клініцистам у підбиранні патогенетичної терапії.

1. Клиническое $\begin{gathered}\text { Література } \\ \text { руководство по черепно- }\end{gathered}$ мозговой травме / Под ред. А.Н. Коновалова, Л.Б. Лихтермана, А.А. Потапова; НИИ нейрохирургии им. Н.Н. Бурденко РАМН. - М., 1998. - T. I. - C. 47-128.

2. Лущик У.Б. Основи клінічної ультразвукової діагностики цереброваскулярних захворювань: артеріальний та венозний аспекти; клініко-гемодинамічні інтерпретація. - К., 1998. $102 \mathrm{c.}$

3. Лущик У.Б. Основы методики ультразвуковой диагностики сосудов головного мозга: артериальный и венозный аспекты, клиническая интерпретация. - К., 1997. - 108 с.

4. Макаров А.Ю. Черепно-мозговая травма / А.Ю. Макаров, В.Г. Помников, П.А. Маккавейский // Клиническая неврология с основами медико-социальной экспертизы / Под ред. Макарова А.Ю. - СПб, 1998. C. 211-232.

5. Одинак М.М. Классификация и клинические проявления последствий черепно-мозговых травм / М.М. Одинак, А.Ю. Емельянов // Воен.-мед. ж. - 1998. - Т. 319,№ 1. - С. 46-51.

6. Патогенез, диагностка и лечение черепномозговой травмы и ее последствий / А.Н. Коновалов, А.А. Потапов, Л.Б. Лихтерман [и др.] // Вопр. нейрохирургии. - 1994. № 4. - С. 18-25.

7. Песочина Э.А. Значение наследственноконституциональных факторов в формировании отдаленных последствий черепномозговой травмы: автореф. дис. на соискание учен. степени канд. мед. наук: спец. 14.00.28. «Нейрохирургия» / Э.А. Песочина. - Харьков, 1989. - 23 c.

8. Рудас М.С. Позитронно-эмиссионная томография в диагностике повреждений головного мозга у больных в отдаленном периоде черепно-мозговой травмы / М.С. Рудас, Т.Ю. Скворцова, А.Д. Коротков // Вопр. нейрохирургии. - 1996. - № 3. - С. 8-12.

9. Черепно-мозкова травма: сучасні принципи невідкладної допомоги: [навч.-метод. посібник] / Є.Г. Педаченко, І.П. Шлапак, А.П. Гук, М.М. Пилипенко. - К.: ВАРТА, 2007. - 312 с.

10. Batjer H.H. Transcranial dopplre pulsativity in vasodilatation and stenosis / H.H. Batjer // J. Neurosurgery. - 1990. - Vol. 72, № 6. P. 901-906.

11. Hashimoto B.E. New Method of Adult Transcranial Doppler / B.E. Hashimoto, C.W. Hattrick // J. Ultrasound Med. - 1991. Vol. 10. - P. 49-53. 


\section{КЛИНИКО-БИОХИМИЧЕСКИЕ СОПОСТАВЛЕНИЯ ПРИ СИНДРОМЕ ВЕГЕТО- СОСУДИСТОЙ ДИСТОНИИ ОТДАЛЕННОГО ПЕРИОДА ЧЕРЕПНО-МОЗГОВОЙ ТРАВМЫ}

\section{Б.В. Задорожная}

Резюме. Приведены результаты допплерографического исследования магистральных артерий головы больных в сопоставлении с клинической симптоматикой доминирующего синдрома вегето-сосудистой дистонии отдаленного периода черепно-мозговой травмы (ЧМТ).

Ключевые слова: отдаленный период ЧМТ, синдром вегето-сосудистой дистонии, транскраниальная допплерография сосудов головы.

\section{CLINICAL AND DOPPLEROGRAPHIC CORRELATES OF VEGETOVASCULAR DYSTONIA SYNDROME OF A REMOTE PERIOD OF TRAUMATIC BRAIN INJURY}

\section{B.V. Zadorozhna}

Abstract. The results represent a dopplerographic study of the great arteries of the head (GAH) and a comparative evaluation of the clinical symptoms of dominant vegetovascular dystonia syndrome in patients of a remote period of traumatic brain injury (TBI).

Key words: remote period of craniocerebral trauma, vegetovascular dystonia syndrome, transcranial dopplerography of cranial vessels.

National Medical University Named after Danylo Halyts'kyi (L’viv)

Рецензент - проф. В.М. Пашковський

Buk. Med. Herald. - 2013. - Vol. 17, № 1 (65). - P. 31-33

Надійшла до редакції 10.08.2012 року

(C) Б.В. Задорожна, 2013

УДК 616.61.-008.9

О.В. Зубаренко, Т.Л. Годлевська, Т.В. Стоєва

\section{КОРЕКЦІЯ УРОДИНАМІЧНИХ РОЗЛАДІВ У ДІТЕЙ ІЗ НЕЙРОГЕННИМИ ДИСФУНКЦІЯМИ СЕЧОВОГО МІХУРА}

Одеський національний медичний університет

Резюме. У роботі наведено результати комплексного уродинамічного та психологічного обстеження 95 дітей із нейрогенними розладами сечового міхура. Показано, що ступінь уродинамічних порушень має прямий лінійний зв'язок із виразністю тривожності пацієн-

Вступ. Порушення сечовипускання в дитячому віці є досить поширеним явищем і трапляється в $30 \%$ дітей віком від 4 до 15 років $[1,11]$. У віці п'яти років нейрогенні порушення спостерігаються в $15-20 \%$, а на момент вступу до школи - у 7-12\% дітей $[1,3,7]$. Уродинаміка нижніх сечовивідних шляхів у дитячому віці значною мірою визначається властивостями психоемоційного стану дитини, його особистісними особливостями сприйняття дії факторів навколишнього середовища [2, 6, 8]. Представляє інтерес дослідження взаємозв'язку рівня тривожності і характеристик уродинамічних порушень 3 боку нижніх сечовивідних шляхів [1, 2, 10]. Існуючі сьогодні терапевтичні підходи при нейрогенних розладах сечовипускання складаються із заходів медикаментозного та немедикаментозного напряму, оцінка ефективності яких зазвичай базується лише на клінічних параметрах, і не перед-

(c) О.В. Зубаренко, Т.Л. Годлевська, Т.В. Стоєва, 2013 тів. Застосування в комплексі терапії динамічної нейроелектростимуляції в комбінації 3 М-холінолітиком справляє потенціювальний коригувальний вплив.

Ключові слова: діти, нейрогенний сечовий міхур, уродинаміка, динамічна нейроелектростимуляції.

бачає комплексного обстеження психологічного та уродинамічного статусу дітей.

Мета дослідження. Вивчити ефективність застосування динамічної електронейростимуляції (ДЕНС) у комплексному лікуванні дітей із нейрогенними розладами сечового міхура $з$ урахуванням виразності тривожності та ступеня уродинамічних порушень.

Матеріал і методи. Обстежено 95 дітей (43 дівчинки та 52 хлопчики) віком від 5 до 11 років (середній вік склав 9,7 $\pm 1,3$ року) із нейрогенними дисфункціями сечового міхура, які розвивалися за гіперактивним типом. Всі діти скаржилися на порушення уродинаміки у вигляді імперативних позивів, епізоди нетримання сечі та часте сечовипускання протягом денного періоду доби.

Оцінку клінічних проявів імперативного сечовипускання проводили згідно з опитувальни- 